\title{
Bir Sembol Olarak "Kilim"
}

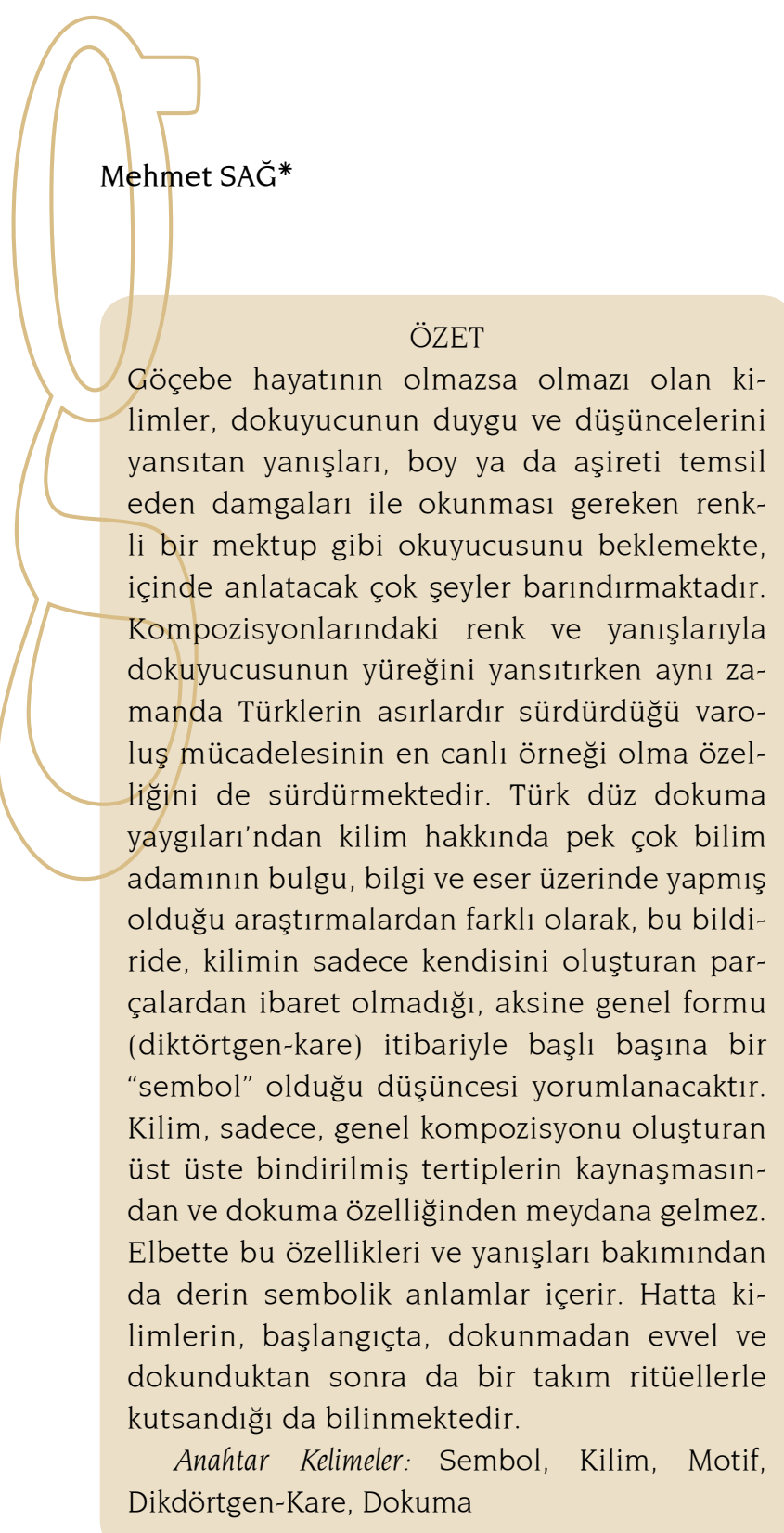

Yrd. Doç. Dr., Yüzüncü Yıl Üniversitesi, Eğitim Fakültesi, Güzel Sanatlar Eğitimi Bölümü, Resim-İş Eğitimi Anabilim Dalı, Kampüs/Van, e-posta: sagmehmet@gmail.com

\section{"Kilim" as a Symbol}

\section{ABSTRACT}

Kilim, which is a sine qua non for nomadic life, waits for the reader, like a letter that should be read, with its motifs reflecting the feelings and thoughts of the reader and its stamps representing a tribe or a clan and it contains lots of things to tell. While reflecting the heart of its weaver with its colours and motifs, at the same time the kilim maintains to be the most vivid sample of struggle for existence which is continued by Turks for centuries. Different from the researches made by lots of scientist on findings, reports and works about the carpet as a Turkish rug, in this paper, the idea that the carpet is not just the parts that form itself but it is a symbol on its own with its general form ( rectanglesquare ) is going to be commented. Carpet does not just consist of combination of overlapping compositions and weaving features. Of course, it contains deep symbolic meanings in terms of these features and motifs. Even more, its known that the carpets are, at first, blessed with a number of rituals just before and after being woven.

Keywords: Symbol, Kilim, Motif, RectangleSquare, Weaving

\section{Giriş}

Kültür, "insanoğlunun öğrenmek, yaşamak, yapmak ve yaratmak için gösterdiği gayretlerden meydana getirdiği bir birikimdir. Çok yönlü, maddi, zihni, estetik ve teknolojik unsurları bulunan bir terkiptir. İnsanı iyiye ve sevgiye yönelten bir kaynak ya da mayadır. Hülasa kültür insan sevgisi demektir. İn- 
sanı, insan yapan gerçek cevher demektir" ${ }^{\prime \prime}$. Kültür ürünleri, kültürel yapının ve yaşama biçiminin en iyi tanıkları ve taşıyıcılarıdır. Bu bağlamda kültürel değerlerin en güzide örneklerini sanat gelenekleri ve bu geleneklerden yansıyan "estetik kriterler"2 oluşturmaktadır. Daha çok toplumların inançları etrafında şekillenen ve dini boyutlarıyla birlikte derin anlamlar kazanan estetik kriterlerin ortaya çıkardığı desenler ve tasarımlar fazla değişikliğe uğramadan günümüze kadar varlıklarını sürdürmüşlerdir. Türk sanatında, özellikle halı ve kilimlerde bu estetik kriterlerin yansımalarını görmek, Türklerdeki inanç felsefesinin kökenleri hakkında fikir sahibi olunmasına olanak sağlamaktadır.

"Geleneksel Türk Düz Dokuma Yaygılar" halkbilimsel (Folklorik) bir olgu olup kültür örneklerinin en canlısıdır ve geleneğe bağlı bir özellik gösterirler. Bir yaratıcılık öğesi olarak da halkın yaşamından kaynaklanan yanışlarla bireylerin ruhsal yaşamlarını yansıtan, toplumsal bir değerdir.

Geleneksel Türk Düz Dokuma Yaygılar'ının en tanınmışı olan kilimlerin Türk insanı tarafından sevilerek dokunması, onun göçebe hayatının vazgeçilmez bir nesnesi olmasındandır. Göçebe hayatının olmazsa olmazı olan kilimler, dokuyucunun duygu ve düşüncelerini yansıtan yanışları, boy ya da aşireti temsil eden damgaları ile okunması gereken renkli bir mektup gibi okuyucusunu beklemekte, içinde anlatacak çok şeyler barındırmaktadır. Kompozisyonlarındaki renk ve yanışlarıyla dokuyucusunun yüreğini yansıtırken aynı zamanda Türklerin asırlardır sürdürdüğü varoluş mücadelesinin en canlı örneği olma özelliğini de göstermektedirler.

Kilimlerin bu kadar parlak ve canlı renklerde dokunmuş olması, kompozisyonlarında canlı cansız birçok varlığın sembolize edilmesi ya da simgeleşmesi; elbette Türklerin doğaya olan sevdasından ve saygısındandır. Fakat kökleri çok eskilere dayalı Şamanî inançların, mitolojik ve kozmolojik ögelerin de tesiri oldukça fazladır. Tüm bu görselleri okuyabilecek ve anlayabilecek en azından bunların birer milli değer olduğunun farkına varabilecek nesillerin yetişmesi, Türk kültürünün devamı için son derece önemlidir.

Türk düz dokuma yaygıları'ndan kilim hakkında pek çok bilim adamının bulgu, bilgi ve eser üze-

S. Kantarcıoğlu, Türkiye Cumhuriyeti Kültür Programlarında Kültür, Kültür ve Turizm Bakanlığı Yayınları, Ankara, 1987, s.7.

2 B. Karamağaralı, "Halı Sanatı Üzerine", Türk Soylu Halkların Halı, Kilim ve Cicim Sanatı Uluslararası Bilgi Şöleni Bildirileri, Atatürk Kültür Merkezi Başkanlığı Yayınları, 27-31 Mayıs 1996, Kayseri, s. 174 . rinde yapmış olduğu araştırmalardan farklı olarak, bu bildiride, kilimin sadece kendisini oluşturan parçalardan ibaret olmadığ $1^{3}$, aksine genel formu (diktörtgen-kare) itibariyle başlı başına bir "sembol" olduğu düşüncesi yorumlanacaktır. Kilim, sadece, genel kompozisyonu oluşturan üst üste bindirilmiş tertiplerin kaynaşmasından ve dokuma özelliğinden meydana gelmez. Elbette bu özellikleri ve yanışları bakımından da derin sembolik anlamlar içerir. Hatta kilimlerin, başlangıçta, dokunmadan evvel ve dokunduktan sonra da bir takım ritüellerle kutsandı ̌̆ı da bilinmektedir. Kilimler, yalnızca kullanım alanları ve dokuma teknikleri açısından değil, varlığıyla da kendisinden daha öte olanı ifade eden Türk Düz Dokuma Yaygıları'ndan biridir. Bu anlamda kilimler bir nesne olmaktan çok bir sembol'dür. O halde "sembol" nedir?

Sembol'ün tam bir tanımını, tek bir cümle altında yapmak oldukça güçtür. Sembol bazen birden çok anlam ve anlatım biçimine sahip kapalı bir kavram olarak karşımıza çıkmaktadır. Bir sembol, birden çok anlama sahip olurken, zaman içerisinde değişik anlamlar da kazanabilmektedir.

Sembol başlangıçta, "sadece görülebilir olanla açığa çıkabilen, görülmez bir realiteyi keşfetmeye yönelten somut bir gerçekçilik" olarak ya da başka bir söyleyişle "bir bütünün parçalarının her birinin bir araya getirilmesiyle ortaya çıkan ve biri olmadan diğerinin anlaşılmadığı önce bir düaliteye sonrasında da bir birleşmeye işaret eden bir kavram"4 olarak tanımlanmaktadır. Sembol'ün farklı disiplinlerde farklı tanımları yapılmıştır. Fakat gerçek olan şudur ki; sembollerde daima bir gizlilik, kapalılık ve çok anlamlılık söz konusudur.

Sembol, en geniş anlamıla her türlü inanışı içinde barındıran, düşünce, yaşayış ve çevrenin biçimlendirdiği sosyal, siyasal, hukuksal, dini ve mistik alanlarda kullanılan ve birden çok ve fark$l_{1}$ anlamlar içeren; somut bir nesne, bir ses ya da davranış, bir renk veya belirli bir zaman kesiti, bir belirti veya işaret, özel bir anlama sahip olay ya da kişi şeklinde tanımlanabilir.

Kilim nesnesi salt biçimiyle derin manalar ortaya koyarken, bu manalar alemi zengin yapısı itibariyle de polifonik bir yapı arz eder. Oğuz bu konuda,"Kilim süslemesinin lügatçesi sembolizmden yana o denli zengindir ki bir kilim süsleme

3 B. Oğuz, Türkiye Halkının Kültür Kökenleri-4," Dokuma ve Giyim Teknikleri", Anadolu Aydınlanma Vakfı Yayınları, İstanbul, Haziran 2004, s. 362.

4 L. Tokat, Dinde Sembolizm, Yayımlanmamış Doktora Tezi, Eylül Üniversitesi Sosyal Bilimler Enst., İzmir, 2002, s. 2. 
ikonografisinden söz etmek yerinde olur. Kilimleri anlamaya çalışırken, kilimi üreten toplumların kültürel bağlamları içinde sembollerin rol ve anlamlarının tetkiki hem ilgili ve uygun, hem de önemli oluyor. Evrensel olarak semboller hatırlatıcı, anlamları vazıh, açık seçik değil, zımnidir" ${ }^{\prime 5}$ derken bu zengin yapının çok sesliliğinden bahsetmektedir.

Kilimin sadece parçalarının toplamından ibaret olmadığına yukarıda değinmiştik. Kilimin tam anlamıyla yapısını anlayabilmek, onu çözümleyebilmek, evvela; onu dokuyan parmakların yaşadığı kültürü ve bu kültüre can veren düşünceyi anlayabilmekle mümkündür. Bu bağlamda Türk düz dokuma yaygılardan biri olan kilimi çözümleyebilmek için, Orta Asya'da göçebe veya yerleşik hayat süren kavimlerin yaşadığı bölgelerdeki iklim özelliklerinden,ekonomik ve sosyal yaşam biçimden, dinsel ve inanış örgüsü ve tüm bunlarla birlikte tüm sanat eserlerinde vücut bulmuş estetik prensiplerden bahsetmek gerekir.

Esin, “...en güzel eserlerin de, en kaba tasvirlerin de menşeini, büyü ile ilgili inanç ve ayinlerinde aramak gerekir"6 derken Türk estetiğinin kaynaklarına da işaret etmektedir.

Kilim, genel formu itibariyle bir dikdörtgen görüntüsünde olup, küp'ün iki boyutlu hali'dir. Semboller sözlüğünde kare şu şekilde açılanmaktadır: "Çevresinden köşeli sınırlarla ayrılmış geometrik biçimlerden biri olan kare, dört rakamının geometrik sembollerinden biridir ve kare şeklini esas alan kübün iki boyutlusu olan şeklidir. Eski Mısır yazısında ve Proto-Türkler'in runik alfabelerinde görülebileceği gibi bir çok yazı sisteminde kullanılan bir karakterdir. Kare sembolü, göğü temsil eden daire ve üçgene kıyasla, Yer'i yani yeryüzünü, tezahür alemini"7 sembolize eder. Ansiklopedik Simgeler Sözlüğüne göre ise kare "Çin ve Orta Asya tasarımlarında üretken bir çift olarak algılanan GökyüzüYeryüzü ikilisinden "Yeryüzü" simgesi" ${ }^{8}$ olarak karşllık bulmaktadır.

Eski Türkler'in dünyayı dörtköşe olarak düşündüklerini ve yakın zamanlara kadar da dünyanın "tört bulunğ" dört köşe ve dört kenarlı olduğunu

5 B. Oğuz, age., s. 361

6 E. Esin, Türk Kültürü El-Kitabı Cilt II, Kısım Ia, İslamiyetten Önceki Türk Sanatı Hakkında Araştırmalar, Milli Eğitim Basımevi, İstanbul, 1972, s. 75 .

7 A. Salt, Ansiklopedi/Neo-spiritüalist Yaklaşımlarla Ezoterik Bilgilerin Işığında/SEMBOLLER, Ruh ve Madde Yayınları, Kasım İstanbul, 2006, s. 195.

8 E. Korkmaz, Ansiklopedik Simgeler Sözlüğü, Anahtar Kitaplar Yayınevi, İstanbul, May1s 2010, s. 701
Türkbilimciler ve Orta Asya halkbilimi göstermektedir. Ayrıca bugünkü Türkçe'deki “dünyanın dört bucağı" deyişi bu düşünceyi kanıtlamaktadır.

Roux, Guillaume de Rubrouck'un yolculuğu sırasında kapalı alanı bulunan mezarlara rastladığını ve bu kapalı alanların düzenli şekilde yontulmamış, bazıları yuvarlak bazıları kare şeklinde büyük taşlarla kapalı olduğunu yazar. Bunların yanında, alanın dört bir köşesinde bulunan ve dünyanın dört bir yanını (simgesel olarak) sınırlayan dört, yüksek dikey taş' $1^{10}$ olduğunu söyler. Türkler'in kare-dikdörtgen düşüncesi üzerine Tekçe'nin şu tespitleri ve yorumu oldukça anlamlıdır:

“Eski Türklerin de dünyayı dört köşe düşündüklerini çeşitli kaynaklardan ve özellikle de Türk söylencesi ile Türk masallarından anlıyoruz. Nitekim Türkbilimci'ler, yüzyıllardır Sibirya'nın ıssız tundralarında dış etkenlerden uzak yaşadıkları için en eski Türk inançlarını yaklaşık bin yıldan beri koruyabilmiş olan Yakut Türkleri'nin yakın zamana kadar "dört köşeli bir dünya” ya inandıklarını yazarlar. Eski Türkler'e göre dünyanın "dört bulunğ", yani dört köşe ve dört kenarlı olduğunu Orta Asya halkbilimi de gösteriyor. Radloff bunun çeşitli örneklerini saptamıştır. Kök-Türk yazıtlarında da o zamanki dünya toplumları tanımlanırken yine "dört bulunğ" daki, yani dört köşedeki, yani dört yandaki budunlardan bahsedilir. Asya Hunları'nın devlet örgütünde de imparatorluğun dört yanı için dört önemli memuriyet varmış. Çok eski bir Türk düşüncesi olduğu anlaşılan bu dört köşe, dört yan kavramı bugünkü Türkçe'mizde de "dünyanın dört bucağı" deyişiyle hala yaşamaktadır. Dört köşe deyimi Türk halk edebiyatında da dünyayı ifade eder. Nihayet, Prof. Divitçioğlu'nun "KökTürkler" adlı yapıtında ayrıntılarıyla aktardığına göre, çeşitli Türk ve yabancı bilim adamları, örneğin, 1931 yılından bu yana F. Köprülü, R. Arat, S. Çağatay, A. Doruk, S. Tezcan, W. Bang, A von le Coq, G. Durand, W. Eberhard, A. Von Gabain ve G. R. Thomsen gibi tarih uzmanları eski Orta Asya kültüründe karenin oturulan kapalı yer, simgesel dilde yurt ve kent ya da surlarla çevrili kale anlamına geldiğini saptamışlardır. Bunun doğal bir sonucu olarak, İskitler'den sonra Hunlar'ın, Kök-Türkler'in ve Uygurlar'ın da yurt-

9 E. F. Tekçe, PAZIRIK Altaylardan Bir Halının Öyküsü, Kültür Bakanlığı Yayınları, Ankara, 1993, s. 96.

10 J. P. Roux, Altay Türkleri'nde Ölüm, Kabalcı Yayınevi, İstanbul, Kasim 1999, s. 309. 
larını kare biçiminde düşündüklerini artık zamanımızda örnekleriyle biliyoruz"11.

Türkler'in arzı ve göğü algılama biçimi Esin'e göre şu şekilde idi:

"Türkler, Çinliler gibi, arzı murabba şeklinde; göğü, o murabbanın içine çizilmiş ve binaenaleyh "dünyanın dört köşesini" kaplamayan bir daire şeklinde tasavvur ederlerdi. Bu köşelerde, dünya nimetlerinden nasibsiz kalan düşmanlar yaşardı. Murabbanın merkezinde, mukaddes dağ (T'ou-kiue'lerde Ötüken) iki kosmik bölgeyi birleştirmekte idi." ${ }^{2}$

Çin arşivlerindeki kayda göre dört köşe adı, Hun ve Türk hükümdarlarının dört başlıca yardımcısına verilen bir $a^{13}{ }^{13}$ olarak geçmektedir. Bu konuda Çoruhlu, çeşitli araştırmacılara dayandırarak Türklerin de Çinlilere benzer şekilde dünyayı bir diktörtgen veya kare biçiminde tasarladıklarını ${ }^{14}$ yazmaktadır.

Ayrıca Türkler'deki dört yön düşüncesi Türk mitolojilerinde belirlenmiş dört renkle sembolleştirilirken, dört coğrafi yöne, değişik renkli atlar yerleştirilmektedir. Bu atlardan dini değeri olan kır at batıya, boz at doğuya, doru atlar güneye ve yağız atlar da kuzeye yerleştirilirdi ${ }^{15}$.

Fuat TEKÇE, Pazırık halısıyla ilgili kitabında halının genel biçimi itibariyle kareye çok yakın olduğundan ve Heredot'un İran budunlarının söylencelerine dayandırarak İskit yurdunun kareye yaklaşık dikdörtgen biçiminde tanımladığını ve İskit topluluklarının da yurtlarını böyle dörtgen biçiminde düşündüklerini ${ }^{16}$ aktarmaktadır.

Türkler'de "mekan" yani "yurt" kutsaldır. "Türk çadırları yani evleri bir yandan evrene benzetilirken öte yandan dünyanın merkezi olarak"17 görülmektedir.

Kilim'in diktörtgen formu tek başına yer'i, yeryüzünü dolayısıyla mekanı sembolize etmektedir. Bu yönüyle kilim nesnesinin bir vatan, bir yurt; en geniş anlamıyla üstünde yaşanan toprak olduğunu söylemek yanlış olmaz. Toprak, sembolik olarak, dişil özellikler içerir, doğurgandır. Kilim üzerine istiflenen ve bu yönüyle de başlı başına sembolik anlamlar taşıyan görsel düzenleme, sanki, dokuyu-

11 E. F. Tekçe, age., s.95, 96, 97.

12 E. Esin, age., s. 77.

13 E. Esin, age., s. 345

14 Y. Çoruhlu, Türk Mitolojisinin ABC'si, Kabalcı Yayınevi, İstanbul, 1999, s. 90.

15 N. Diyarbekirli, Hun Sanatı, Milli Eğitim Bakanlığı Kültür Yayınları, İstanbul, 1972, s. 60

16 E. F. Tekçe, age., s. 95, 96.

17 M. Eliade, Dinler Tarihine Giriş, Kabalcı Yayınevi, İstanbul, Ocak 2003, s. 366. cunun üstünde yaşadı ̆̆ı vatan toprağının tüm güze lliklerini,yokluklarını,zorluklarını, mistik değerlerini dokuyucunun duygularıyla birlikte sergiler. Kare, dolayısıyla dikdörtgen formlar insana güven verir. Kendini güven içinde hissettiği mekanı güzelleştirmek, onunla olan organik bağını estetik değerlerle yaşanılır hale getirmek, dokuyucu için, kutsal bir görev gibi algılanmakta ve bir takım ritüellerle dokuma görevi yerine getirilmektedir.

Dokuma işinin bir rastlantı olmadığını, onun önceden düşünülmüş bilinçli bir tasarım olduğunu ifade eden düşünceler TEKÇE'nin "Pazırık” kitabında şu şekilde geçmektedir:

“...Pazırık halısının düzeni, düzenin doğurduğu, kareye yaklaşık dört köşe biçimi ve bu düzen içerisindeki motiflerin yerleştirilmesi, sanırım, bir rastlantı değildir; üzerinde düşünülmüş, bilerek öyle seçilmiş, bilerek öyle yapılmıştır. Çünkü, bir halının ölçüleri ile düzenini biçim etkiler. Ve bu düzenin nasıl bir biçime, biçimin de nasıl bir düzene elvereceği bilinir. Eğer biçim olarak kareye yaklaşık bir alan ya da diktörtgen arzulanıyorsa, genel düzen ona göre yapılır, bordürlerin orta alana oranı, genişlikleri, sayısı, bütün bunlardan ötürü de-çözgü tellerinin miktarı, çözgü, atkı ve dokuma ipliğinin inceliği ile tezgahın türü, ölçüleri ve düzeni gibi-hesap kapısına çıkan teknik ayrıntılar ona göre saptanır ve motifler düzenleme içerisinde ona göre yerleştirilir. Daha açık bir deyişle, bir yapının planı arsanın çaplarına ve arazinin durumuna nasıl uyduruluyorsa, başarılı bir halıda da rastlantıya hemen hemen hiç yer yoktur ve bütün ayrıntılar ile halının tümü önceden ince ince düşünülmüştür ${ }^{18}$.

Selçuk Mülayimin de belirttiği gibi kilimler de tıpkı hasır yaygılar ve hayvan postlarında olduğu şekliyle renksiz ve desensiz dokunabilirdi. Eğer kilim dokuması renkli ve desenli dokunmuşsa, bunu dokumacı istemiştir. Dokumacı bezemiş olduğu yüzeyle, biçime manevi bir derinlik ve öz kazandırmakta, o eşyayı kimlikli kılmaktadır ${ }^{19}$.

Türklerin cenneti, evreni ve dünyayı anlama, algılama ya da düşünme biçimi olarak olsun karedikdörtgen biçiminin Türk kültürünün köklü işareti olduğu gerçeği bugün gün gibi ortadadır. Tüm bu gerçekler içerisinde ortaya çıkmış, çıkan ve çıkacak

18 E. F. Tekçe, age., s. 155, 156.

19 S. Mülayim, "Tanımsız Figürlerin İkonografisi", Türk Soylu Halkların Hall, Kilim ve Cicim Sanatı Uluslararası Bilgi Şöleni Bildirileri, Atatürk Kültür Merkezi Başkanlığı Yayınları, 27-31 Mayıs, Kayseri, 1996, s. 220. 
olan halı, kilim ve benzeri eserlerde bir "estetik kriter", bir "dini ritüel" veya bir "dini mana" vardır. Kilimleri dokumaya başlamadan önce inanışa bağlı bir uygulamayı Durul bize şu şekilde aktarmaktadır:

“Özellikle çeyiz için dokunan kilim tezgâha bağlanıp gelin kız dokumaya başlamadan yaratıcı Tanrıya horoz kurban edilir. Maniler okunur. Türküler söylenir.

Biz geçmişi yâd ettik

Horozları şad ettik

Hızır bizi anladı

Kendi gelip bağladı." ${ }^{20}$

Dokuma işi bir yaratılış bir doğum işidir. Dokuma bitirildiğinde dokumacı tarafından tezgâha bağlı olan iplikleri kesilir ve bu yapılırken bir kutsama, hayır dua sözleri telaffuz edilir. Bu sözler, yeni doğmuş bir çocuğun göbeğinin ebe tarafından kesilişi esnasında söylenen sözlerle aynı olan sözlerdir. Dokuma konusunu araştıranlar, dokumanın kökenini kadın dünyasına taşıma konusunda aynı fikirde olmuşlardır. Bu düşüncelerini de sayısız sembolik bağlantılarla desteklemişlerdir. Dokumayı yaratılışın bir sureti, iki karşıtın-çözgü ve atkıbirleşmesinden meydana gelen bir doğum ${ }^{21}$ olarak görmektedirler.

Kilimler, kimi zaman "dostane bir varlık", kimi zaman da "rüzgâr ve kumdan koruyan" bir kalkan olmaktadır. Bazen, "masa ya da yatak olarak" bazen da "tartışmalar ve gevezelikler için bir sosyal alan" olarak kullanılmaktadır. Kimi zaman da "yavrular için beşik", "cenazede tabut örtüsü" veya "dua için bir yer işlevini" görmektedir.

Kilimlerle kadın arasındaki en önemli ilişki, her ikisinin de dişil özelliklerle donanmış olmasındandır. Kilim için seçilen elyaf başta olmak üzere, kullanılan doğal boya ve seçilen yanışlar tamamen organik düzenin bir ürünü, bir yansımasıdır. Dokuyucu, dokumasındaki organik yapıyı düzenlerken bağlı bulunduğu topluluğun sosyal, siyasi, hukuksal, dini ve mistik özelliklerinin yanı sıra kişisel duygu ve düşüncelerini de tasarımı içerisinde vermektedir. Vatan toprağı üzerinde yaşanmış ve yaşanmakta olan, onun üzerinde hayal edilenin konu alındığı bir tasarıma ev sahipliği yapan kilim, bu ve benzer yönleriyle başlı başına bir semboldür.

\section{Kaynaklar}

Çoruhlu, Yaşar (1999), Türk Mitolojisinin ABC'si, Kabalcı Yayınevi, İstanbul.

Diyarbekirli, Nejat (1972), Hun Sanatı, Milli Eğitim Bakanlığı Kültür Yayınları, İstanbul.

Durul, Yusuf (1977), Yörük Kilimleri (Niğde Yöresi), Ak Yayınları Türk Süsleme Serisi: 6, İstanbul.

Eliade, Mircea (2003), Dinler Tarihine Giriş, Kabalcı Yayınevi, Ocak, İstanbul.

Esin, Emel (1972), Türk Kültürü El-Kitabı Cilt II, Kısım Ia, İslamiyetten Önceki Türk Sanatı Hakkında Araştırmalar, Milli Eğitim Basımevi, İstanbul.

Kantarcioğlu, Selçuk (1987), Türkiye Cumhuriyeti Kültür Programlarında Kültür, Kültür ve Turizm Bakanlığı Yayınları, Ankara.

Karamağaralı, Beyhan (27-31 Mayıs 1996), "Halı Sanatı Üzerine", Türk Soylu Halkların Halı, Kilim ve Cicim Sanatı Uluslararası Bilgi Şöleni Bildirileri, Atatürk Kültür Merkezi Başkanlığı Yayınları, Kayseri.

Korkmaz, Esat (Mayıs 2010), Ansiklopedik Simgeler Sözlügü̈, Anahtar Kitaplar Yayınevi, İstanbul.

Mülayim, Selçuk (27-31 Mayıs 1996), "Tanımsız Figürlerin İkonografisi", Türk Soylu Halkların Hall, Kilim ve Cicim Sanatı Uluslararası Bilgi Şöleni Bildirileri, Atatürk Kültür Merkezi Başkanlığı Yayınları, Kayseri.

Oğuz, Burhan (Haziran 2004), Türkiye Halkının Kültür Kökenleri-4," Dokuma ve Giyim Teknikleri", Anadolu Aydınlanma Vakfı Yayınları, İstanbul.

Özkeçeci, İlhan (2004), Zamanı Aşanlar IX. Yüzyıla Kadar Türk Sanatı, HMS Grup Yayınları, İstanbul.

Roux, Jean-Paul (Kasım 1999), Altay Türkleri'nde Ölüm, Kabalcl Yayınevi, İstanbul.

Salt, Alparslan (Kasım 2006), Ansiklopedi/Neo-spiritüalist Yaklaşımlarla Ezoterik Bilgilerin Işı̆̆ında/ Semboller, Ruh ve Madde Yayınları, İstanbul.

Tekçe, E. Fuat (1993), PAZIRIK Altaylardan Bir Halının Öyküsü, Kültür Bakanlığı Yayınları, Ankara.

Tokat, Latif (2002), Dinde Sembolizm, Yayımlanmamış Doktora Tezi, Eylül Üniversitesi Sosyal Bilimler Enstitüsü, İzmir.

\footnotetext{
20 Y. Durul, Yörük Kilimleri (Niğde Yöresi), Ak Yayınları Türk Süsleme Serisi: 6, İstanbul, 1977, s. 16.

21 B. Oğuz, age., s. 357.
} 
